\title{
A checklist of the termites of Kruger National Park, South Africa
}

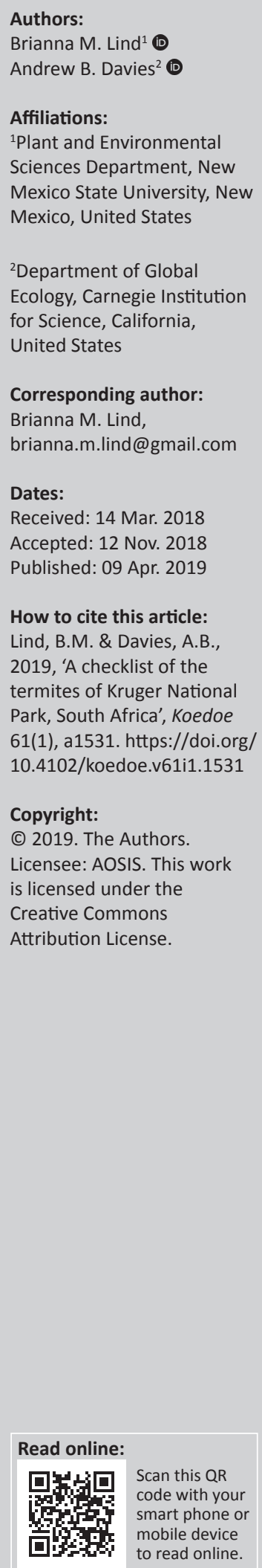

The protection of biodiversity is critical to ecosystem function and is a primary management goal for conservation areas globally. Maintaining a current inventory of known diversity is a central component of achieving this goal and serves as an essential starting point for future research endeavours. Since the first published survey of termites in South Africa's Kruger National Park (KNP) over 55 years ago, our understanding of termite diversity has expanded sufficiently to merit an update and formal checklist. Here we revise the inventory of termite diversity in KNP and summarise the taxonomic and functional diversity of termites in the park. A thorough review of recent termite research in KNP added 6 new genera and 13 species to what was found in Coaton's original survey, with one genus, Anenteotermes, recorded for the first time in southern Africa. Based on the updated species checklist, the majority of genera in the park belong to Feeding Group II (39\%) and the Termitidae family (75\%).

Conservation implications: In savannas, termites play crucial roles in nutrient cycling, water redistribution and plant dynamics. Systematically cataloguing termite diversity and assemblage composition in the park provides an essential baseline for scientific research, aids biodiversity conservation efforts and encourages scientists and managers to consider termites in ecosystem functioning and management. Having more detailed descriptions of genera, species and feeding groups allows for more tangible, ecologically relevant attributions of termite influence, facilitates enhanced inquiry and allows for more realistic quantification of termite roles in key ecosystem processes.

Keywords: termite; Kruger National Park; feeding groups; diversity; savanna.

\section{Introduction}

A principal goal of most conservation areas is to conserve biodiversity in all its facets. To achieve this goal, scientists must first catalogue the known diversity of organisms to serve as a baseline for future conservation and research endeavours. This is particularly pertinent for groups that perform important ecological functions, such as termites. Termites are a prominent source of habitat heterogeneity in African savannas and have a substantial impact on ecosystem functioning (Jouquet et al. 2011; Sileshi et al. 2010). Termites are the dominant invertebrate decomposers in tropical forests and savannas (Collins 1981; Schuurman 2005), and, through their foraging activities, alter soil processes, redistribute nutrients and modify soil hydrology (Jouquet et al. 2011). These ecosystem alterations in turn affect vegetation distributions and assemblage composition (Davies, Baldeck \& Asner 2016a; Joseph et al. 2014; Sileshi et al. 2010), resulting in a patchy landscape that alters both mammalian and insect herbivore foraging behaviour (Davies et al. 2016b, 2016c; Grant \& Scholes 2006; Levick et al. 2010a).

Considering its latitude, southern Africa has a surprisingly high diversity of termites, with over 50 genera present (Eggleton 2000; Uys 2002). The termite fauna of the region is generally considered to be well documented as a result of the National Survey of Isoptera conducted by W.G.H. Coaton and co-workers between 1956 and 1979. During this survey, almost every quarter-degree grid cell of South Africa, Swaziland, Zimbabwe and Namibia was sampled for termites. Much of the information gained from this survey appeared in a series of publications in Cimbebasia between 1971 and 1980 (Uys 2002), and collected specimens are currently located in the South African National Collection of Insects (Uys 2002). Kruger National Park (KNP), South Africa, was also included in these surveys, with a checklist of the park's termite fauna published in 1962 (Coaton 1962). However, since this time, a considerable amount of termite research has been conducted in $\mathrm{KNP}$, warranting an update of the checklist in order to have a comprehensive and current inventory of termite diversity in the park.

In his survey, Coaton collected 22 termite genera from four families within KNP (Coaton 1962). While the last few decades have seen a large increase in the number of studies investigating 
termite ecology in KNP, none have focused exclusively on termite taxonomy or sought to update the checklist, despite new genus and species records. Here we synthesise the termite occurrence records from published studies in KNP and compile an updated list of termite richness and functional diversity to facilitate better understanding of $\mathrm{KNP}^{\prime} \mathrm{s}$ biodiversity, which will aid both management and future research endeavours. By characterising the park's termite assemblages, a fuller understanding of the fundamental roles termites play in critical ecosystem processes within Kruger's savannas can also be realised.

\section{Methods and materials}

Kruger National Park is located in low-lying savanna in the northeast corner of South Africa between the foot slopes of the Drakensberg Escarpment and Mozambican coastal plains (Venter, Scholes \& Eckhardt et al. 2003). The region experiences high temperatures in the summer, mild winters and the majority of rainfall between October and April (ranging from $\sim 300 \mathrm{~mm} /$ year in the north to $\sim 700 \mathrm{~mm} /$ year in the south) (Venter et al. 2003). The park has two main underlying geologies, basalt in the east and granite in the west (Venter et al. 2003). Along with varying rainfall, these geologies contribute to a diverse range of soil types and influence vegetation patterns (Venter et al. 2003). Tree canopy cover ranges from $5 \%$ to $60 \%$, and $75 \%$ of the park is covered by broad-leaved savanna with the remaining $25 \%$ composed of fine-leaved savanna (Venter et al. 2003).

We conducted a comprehensive literature review of research involving termites in KNP by searching Web of Science and Google Scholar and compiled a list of termite genera and species sampled from each study. Termites were listed by family, subfamily, genus and species and categorised into feeding groups (FG) following Donovan, Eggleton and Bignell (2001) to characterise the assemblage. Feeding groups consist of four categories (I-IV) based on the level of decay of food items, which ranged from live plants to decayed organic material. Donovan et al. (2001) defines FGs to include a nontermitid group, FG-I, that feeds on dead wood and grass and three termitid groups that eat dead wood, litter and microepiphytes, FG-II, humus, FG-III, and soil minerals, FG-IV.

\section{Results}

Our literature review of 20 termite-related studies conducted in KNP (see Table 1) revealed that since Coaton's 1962 survey, six previously unlisted termite genera and 13 species have been sampled in the park (see Table 2). In addition, one sampled genus, Anenteotermes, had not been previously recorded in southern Africa. Three studies in particular contributed to checklist updates: Meyer et al. (1999); Davies et al. (2012); and Davies et al. (2014a). While termites from all southern African families are present in the park, the majority (75\%) belong to the Termitidae family (see Figure 1a). In terms of FGs, FG-II makes up $40 \%$ of termite genera in the park, FG-I and FG-III each make up 25\% and FG-IV, which is the least represented, makes up $10 \%$ (see Figure $1 \mathrm{~b}$ ).

\section{Discussion}

Termite ecology in KNP, and in savannas globally, has advanced substantively since Coaton's 1962 survey. Our literature review revealed 6 previously unrecorded genera and 13 previously unrecorded species in KNP. Termite diversity in KNP appears to mirror the generalised diversity pattern of termites in southern Africa, with relatively few genera in the Hodotermitidae, Kalotermitidae and Rhinotermitidae families, with the majority of termite diversity being found within the Termitidae family (Uys 2002). As knowledge about how termites affect the structure and function of savanna ecosystems continues to

TABLE 1: History of published, termite-focused research conducted in the Kruger National Park, South Africa.

\begin{tabular}{|c|c|c|}
\hline Year of Publication & Authors & Title \\
\hline 1962 & Coaton, W.G.H. & $\begin{array}{l}\text { Survey of the termites of Kruger National } \\
\text { Park }\end{array}$ \\
\hline 1995 & Braack, L.E.O. & $\begin{array}{l}\text { Seasonal activity of savanna termites during } \\
\text { and after a severe drought }\end{array}$ \\
\hline 1999 & Meyer, V.W. et al. & $\begin{array}{l}\text { Distribution and density of termite mounds in } \\
\text { the northern Kruger National Park, with } \\
\text { specific reference to those constructed by } \\
\text { Macrotermes Holmgren (Isoptera: Termitidae) }\end{array}$ \\
\hline 2000 & Meyer, V.W. et al. & $\begin{array}{l}\text { Distribution and density of Cubitermes } \\
\text { Wasmann (Isoptera: Termitidae) mounds in } \\
\text { the northern Kruger National Park }\end{array}$ \\
\hline 2000 & Meyer, V.W. et al. & $\begin{array}{l}\text { Intracolonial demography of the } \\
\text { mound-building termite Macrotermes } \\
\text { natalensis (Haviland) (Isoptera, Termitidae) } \\
\text { in the northern Kruger National Park, } \\
\text { South Africa }\end{array}$ \\
\hline 2001 & Meyer, V.W. et al. & $\begin{array}{l}\text { Biomass of Macrotermes natalensis in } \\
\text { the northern Kruger National Park, } \\
\text { South Africa - the effects of land } \\
\text { characteristics }\end{array}$ \\
\hline 2003 & Meyer, V.W. et al. & $\begin{array}{l}\text { Estimates of food consumption by the } \\
\text { fungus-growing termite Macrotermes } \\
\text { natalensis in a South African savanna- } \\
\text { woodland: news and views }\end{array}$ \\
\hline 2005 & Sponheimer et al. & $\begin{array}{l}\text { Hominins, sedges, and termites: new carbon } \\
\text { isotope data from the Sterkfontein valley } \\
\text { and Kruger National Park }\end{array}$ \\
\hline 2006 & Grant \& Scholes & $\begin{array}{l}\text { The importance of nutrient hot-spots in the } \\
\text { conservation and management of large wild } \\
\text { mammalian herbivores in semi-arid } \\
\text { savannas }\end{array}$ \\
\hline 2010 & Levick et al. & $\begin{array}{l}\text { Regional insight into savanna } \\
\text { hydrogeomorphology from termite mounds }\end{array}$ \\
\hline 2010 & Levick et al. & $\begin{array}{l}\text { The spatial extent of termite influences on } \\
\text { herbivore browsing in an African savanna }\end{array}$ \\
\hline 2012 & Coetsee et al. & $\begin{array}{l}\text { An overview of nitrogen cycling in a } \\
\text { semi-arid savanna: some implications for } \\
\text { management and conservation in a large } \\
\text { African park }\end{array}$ \\
\hline 2012 & Davies et al. & $\begin{array}{l}\text { The pyrodiversity-biodiversity hypothesis: } \\
\text { a test with savanna termite assemblages }\end{array}$ \\
\hline 2013 & Davies et al. & $\begin{array}{l}\text { Assessing the relative efficiency of termite } \\
\text { sampling methods along a rainfall gradient } \\
\text { in African savannas }\end{array}$ \\
\hline 2014 & Davies et al. & $\begin{array}{l}\text { Variable effects of termite mounds on } \\
\text { African savanna grass communities across a } \\
\text { rainfall gradient }\end{array}$ \\
\hline 2014 & Davies et al. & $\begin{array}{l}\text { Spatial variability and abiotic determinants } \\
\text { of termite mounds throughout a savanna } \\
\text { catchment }\end{array}$ \\
\hline 2015 & Davies et al. & $\begin{array}{l}\text { Seasonal activity patterns of African } \\
\text { savanna termites vary across a rainfall } \\
\text { gradient }\end{array}$ \\
\hline 2016 & Davies et al. & $\begin{array}{l}\text { Termite mounds alter the spatial } \\
\text { distribution of African savanna tree species }\end{array}$ \\
\hline 2016 & Davies et al. & $\begin{array}{l}\text { Termite mounds differ in their importance } \\
\text { for herbivores across savanna types, } \\
\text { seasons and spatial scales }\end{array}$ \\
\hline 2016 & Joseph et al. & $\begin{array}{l}\text { Microclimates mitigate against hot } \\
\text { temperatures in dryland ecosystems: } \\
\text { termite mounds as an example }\end{array}$ \\
\hline
\end{tabular}


TABLE 2: Checklist of termites known to occur in the Kruger National Park, South Africa.

\begin{tabular}{|c|c|c|c|c|c|c|c|}
\hline Family & Subfamily & Genus & Species & $\begin{array}{c}\text { Original } \\
\text { Coaton (1962) } \\
\end{array}$ & $\begin{array}{c}\text { Added by Meyer } \\
\text { (1999) }\end{array}$ & $\begin{array}{l}\text { Added by Davies } \\
\text { et al. (2012) }\end{array}$ & FG \\
\hline \multirow[t]{4}{*}{ Kalotermitidae } & - & Cryptotermes & spp. & $\mathrm{x}$ & - & - & 1 \\
\hline & & Epicalotermes & spp. & $\mathrm{x}$ & - & - & 1 \\
\hline & & Bifiditermes & spp. & $\mathrm{x}$ & - & - & I \\
\hline & & Neotermes & spp. & $\mathrm{x}$ & - & - & 1 \\
\hline \multirow[t]{2}{*}{ Hodotermitidae } & - & Hodotermes & spp. & $x$ & - & - & 1 \\
\hline & & & mossambicus & - & - & $x$ & 1 \\
\hline \multirow[t]{2}{*}{ Rhinotermitidae } & - & Psammotermes & spp. & $x$ & - & - & I \\
\hline & & Schedorhinotermes & spp. & $x$ & - & - & 1 \\
\hline \multirow[t]{30}{*}{ Termitidae } & Macrotermitinae & Allodontermes & spp. & $x$ & - & - & II \\
\hline & & & rhodesiensis & - & - & $\mathrm{x}$ & II \\
\hline & & Ancistrotermes & spp. & $\mathrm{x}$ & - & - & II \\
\hline & & & latinotus & - & - & $\mathrm{x}$ & II \\
\hline & & Macrotermes & spp. & $\mathrm{x}$ & - & - & II \\
\hline & & & michaelseni & - & $x$ & - & II \\
\hline & & & natalensis & - & $\mathrm{x}$ & - & II \\
\hline & & & ukuzii & - & $\mathrm{x}$ & - & II \\
\hline & & Microtermes & spp. & $\mathrm{x}$ & - & - & II \\
\hline & & Odontotermes & spp. & $\mathrm{x}$ & - & - & II \\
\hline & & & prob. Latericius & - & $x$ & - & II \\
\hline & Apicotermitinae & Adaiphrotermes & spp. & - & - & $\mathrm{x}$ & III \\
\hline & & Alyscotermes & spp. & - & - & $\mathrm{x}$ & III \\
\hline & & Anenteotermes & spp. & - & - & $\mathrm{x}$ & III \\
\hline & & Apicotermes & spp. & $\mathrm{x}$ & - & - & IV \\
\hline & & Astalotermes & spp. & - & - & $\mathrm{x}$ & III \\
\hline & Termitinae & Amitermes & spp. & $\mathrm{x}$ & - & - & II \\
\hline & & & hastatus & - & - & $\mathrm{x}$ & II \\
\hline & & & messinae & - & - & $\mathrm{x}$ & II \\
\hline & & Cubitermes & spp. & $\mathrm{x}$ & - & - & IV \\
\hline & & Lepidotermes & spp. & $\mathrm{x}$ & - & - & IV \\
\hline & & Microcerotermes & spp. & $\mathrm{x}$ & - & - & II \\
\hline & & Promirotermes & spp. & $\mathrm{x}$ & - & - & III \\
\hline & Nausitermitinae & Fulleritermes & spp. & $x$ & - & - & II \\
\hline & & Coarctotermes & spp. & $\mathrm{x}$ & - & - & II \\
\hline & & Rhadinotermes & spp. & - & - & $\mathrm{x}$ & II \\
\hline & & & coarctus & - & - & $\mathrm{x}$ & II \\
\hline & & Trinervitermes & spp. & $x$ & - & - & II \\
\hline & & & dispar & - & $x$ & - & II \\
\hline & & & trinervoides & - & $x$ & - & II \\
\hline
\end{tabular}

No. Genera, Original - Coaton (1962) = 22; Added by Meyer (1999) = 0; Added by Davies et al. $(2012)=6$.

No. Species, Original - Coaton (1962) $=0$; Added by Meyer (1999) $=5$; Added by Davies et al. $(2012)=6$.

FG, feeding group.

accumulate, it will be increasingly important to understand how different species and genera interact with and affect the environment. Maintaining an accurate record of the termites that occur in KNP is a critical first step to achieving this understanding and provides an essential baseline for ongoing research.

There were two major research papers that contributed most significantly to updating the inventory of KNP's taxonomic diversity: Meyer et al. (1999), and Davies et al. (2012). Meyer et al. (1999) made substantial contributions to advancing our understanding of termite diversity in KNP through research that involved mapping the distribution and density of termite mounds in northern Kruger (Meyer et al. 1999, 2000a). Meyer et al. (1999) documented Macrotermes natalensis as the most abundant mound-building termite species in this region, which led to several follow-up studies on the species, including an investigation of intracolonial demography (Meyer et al. 2000), biomass (Meyer et al. 2001) and food consumption (Meyer et al. 2003). While Meyer's research into $M$. natalensis provides an excellent baseline for the ecological influence of this termite species in northern KNP, future research should strive to account for the full breath of foraging power (i.e. litter removal) that all FG-II termites effect in KNP. When FG-II termites are evaluated collectively, we may find that litter removal by termites competes with burning and herbivory and could in turn subsequently influence fire regimes and patterns.

While Meyer et al. (1999) increased our knowledge of mound-building termites, Davies et al. (2012) employed a 




FIGURE 1: Summary of the families (a) and feeding groups (b) of termites sampled in Kruger National Park, South Africa.

broad range of sampling strategies that captured the full range of termite families in the park. Davies et al. (2012) sampled termites across varying burning regimes across KNP and found that termites are broadly resilient to fire. They found that FG-II termites are dominant across KNP's rainfall gradient with the caveat that the proportion of other FGs changed with rainfall, with the greatest FG diversity in the wettest region, Pretoriuskop. This overall finding is similar to our synthesis, where we also found a dominance of FG-II termites in KNP. Davies et al. (2012) also documented a first record of the soil-feeding genus Anenteotermes (Sands 1998) in KNP and in southern Africa. Although this genus is known to range from semi-arid savanna to rainforests (Sands 1998), Davies et al. (2012) were the first to document the genus in southern Africa. Anenteotermes has previously been recorded from as far south as Malawi (Donovan et al. 2002) and is also well represented in central (e.g. Deblauwe et al. 2008; Eggleton et al. 1996) and east (e.g. Wanyonyi et al. 1984) Africa.

Although we have added numerous additions to Coaton's original 1962 checklist, many of the specimens he sampled still await identification. As such, our 'new' findings compiled from recent research may be a consequence of a more comprehensive identification process rather than of sampling in a new environment. This highlights the lack of taxonomic resolution of termites (especially non-moundbuilding, soil-feeding termites) in Africa. Indeed, almost a third of termite genera in southern Africa are in need of taxonomic revision (Uys 2002). Because listing and categorising taxa is such an important component of conserving biodiversity and understanding ecosystems, a priority of future termite research should be to resolve these taxonomic difficulties (Wilson 2017). Deoxyribonucleic acid metabarcoding, in conjunction with taxonomic and natural history data components, may facilitate enhanced taxonomic clarity and enable more species-level identifications.

\section{Conclusion}

Collectively, termites as an insect group play considerably important roles in the functioning of dryland and subtropical environments. Maintaining a termite checklist in KNP allows us to begin the important work of attributing what we understand as 'termite influence' to specific termite species and genera. It also provides an invaluable baseline for future research in the park and facilitates the implementation of biodiversity conservation, a key park management goal. The ecological significance and conservation value of insects in savannas has traditionally received little attention relative to vertebrates (Braack \& Kryger 2003). Knowledge of termite diversity and assemblage composition will hopefully help bridge this gap and facilitate the consideration of this important insect group in ecosystem functioning and management planning. Moving forward, assessing termite diversity in ecologically relevant FGs, that have targeted and discernible ecosystem impacts, will advance research endeavours and allow for more realistic quantification of their roles in key processes such as vegetation dynamics, nutrient cycling, litter removal and fuel-load management.

\section{Acknowledgements}

The authors would like to thank Dr Niall Hanan for insightful comments on an earlier version of the manuscript.

\section{Competing interests}

The authors declare that they have no financial or personal relationships that may have inappropriately influenced them in writing this article.

\section{Authors' contributions}

B.M.L. and A.B.D. designed the study, analysed the data and wrote the article. 


\section{References}

Braack, L.E.O., 1995, 'Seasonal activity of savanna termites during and after severe drought', Koedoe 38, 73-82. https://doi.org/10.4102/koedoe.v38i1.307

Braack, L.E.O. \& Kryger, P., 2003, 'Insects and savanna heterogeneity', in J.T. Du Toit, K.H. Rogers \& H.C. Biggs (eds.), The Kruger experience: Ecology and management of savanna heterogeneity, pp. 83-129, Island Press, Washington, DC.

Coaton, W.G.H., 1962, 'Survey of the termites of the Kruger National Park', Koedoe 5, 144-168. https://doi.org/10.4102/koedoe.v5i1.842

Coetsee, C., Jacobs, S. \& Govender, N., 2012, 'An overview of nitrogen cycling in a semiarid savanna: Some implications for management and conservation in a large African park', Environmental management 49, 387-402. https://doi.org/10.1007/ s00267-011-9779-0

Collins, N.M., 1981, 'Populations, age structure, and survivorship of colonies of Macrotermes bellicosus (Isoptera: Macrotermitinae)', Journal of Animal Ecology 50, 293-311. https://doi.org/10.2307/4046

Davies, A.B., Baldeck, C.A. \& Asner, G.P., 2016a, 'Termite mounds alter the spatial distribution of African savanna tree species', Journal of Biogeography 43, 301-313. https://doi.org/10.1111/jbi.12633

Davies, A.B., Eggleton, P., Van Rensburg, B.J. \& Parr, C.L., 2012, 'The pyrodiversitybiodiversity hypothesis: A test with savanna termite assemblages', Journal of Applied Ecology 49, 422-430. https://doi.org/10.1111/j.1365-2664.2012.02107.x

Davies, A.B., Eggleton, P., Van Rensburg, B.J. \& Parr, C.L., 2013, 'Assessing the relative efficiency of termite sampling methods along a rainfall gradient in African savannas', Biotropica 45, 474-479. https://doi.org/10.1111/btp.12030

Davies, A.B., Eggleton, P., Van Rensburg, B.J. \& Parr, C.L., 2015, 'Seasonal activity patterns of African savanna termites vary across a rainfall gradient', Insectes Sociaux 62, 157-165. https://doi.org/10.1007/s00040-014-0386-y

Davies, A.B., Levick, S.R., Asner, G.P., Robertson, M.P., Van Rensburg, B.J. \& Parr, C.L., 2014a, 'Spatial variability and abiotic determinants of termite mounds throughout a savanna catchment', Ecography 37, 852-862. https://doi.org/10.1111/ecog. 00532

Davies, A.B., Levick, S.R., Robertson, M.P., Van Rensburg, B.J., Asner, G.P. \& Parr, C.L., 2016b, 'Termite mounds differ in their importance for herbivores across savanna types, seasons and spatial scales', Oikos 125, 726-734. https://doi.org/10.1111/ oik.02742

Davies, A.B., Robertson, M.P., Levick, S.R., Asner, G.P., Van Rensburg, B.J. \& Parr, C.L., 2014, 'Variable effects of termite mounds on African savanna grass communities across a rainfall gradient', Journal of Vegetation Science 25, 1405-1416. https:// doi.org/10.1111/jvs.12200

Davies, A.B., Van Rensburg, B.J., Robertson, M.P., Levick, S.R., Asner, G.P. \& Parr, C.L., $2016 \mathrm{c}$, 'Seasonal variation in the relative dominance of herbivore guilds in an African savanna', Ecology 97, 1618-1624. https://doi.org/10.1890/15-1905.1

Deblauwe, I., Dibog, L., Missoup, A.D., Dupain, J., Van Elsacker, L., Dekoninck, W. et al., 2008 , 'Spatial scales affecting termite diversity in tropical lowland rainforest: A case study in southeast Cameroon', African Journal of Ecology 46, 5-18. https:// doi.org/10.1111/j.1365-2028.2007.00790.x

Donovan, S.E., Eggleton, P. \& Bignell, D.E., 2001, 'Gut content analysis and a new feeding group classification of termites', Ecological Entomology 26, 356-366. https://doi.org/10.1046/j.1365-2311.2001.00342.x

Donovan, S.E., Eggleton, P. \& Martin, A., 2002, 'Species composition of termites of the Nyika plateau forests, northern Malawi, over an altitudinal gradient', African Journal of Ecology 40, 379-385. https://doi.org/10.1046/j.1365-2028.2002.00397.x

Eggleton, P., 2000, 'Global patterns of termite diversity', in T. Abe \& M. Higashi (eds.), Termites: Evolution, sociality, symbioses, ecology, pp. 25-51, Springer, Netherlands.

Eggleton, P., Bignell, D.E., Sands, W.A., Mawdsley, N.A., Lawton, J.H., Wood, T.G. et al., 1996, 'The diversity, abundance and biomass of termites under differing levels of disturbance in the Mbalmayo Forest Reserve, southern Cameroon', Philosophical Transactions of the Royal Society of London B 351, 51-68. https://doi.org/10.1098/ rstb.1996.0004
Grant, C.C. \& Scholes, M.C., 2006, 'The importance of nutrient hot-spots in the conservation and management of large wild mammalian herbivores in semi-arid savannas', Biological Conservation 130, 426-437. https://doi.org/10.1016/j. savannas', Biological

Joseph, G.S., Seymour, C.L., Coetzee, B.W.T., Ndlovu, M., De La Torre, A., Suttle, R. et al., 2016, 'Microclimates mitigate against hot temperatures in dryland ecosystems: Termite mounds as an example', Ecosphere 7, 1-10. https://doi. ocosystems: Termite

Joseph, G.S., Seymour, C.L., Cumming, G.S., Cumming, D.H. \& Mahlangu, Z., 2014, 'Termite mounds increase functional diversity of woody plants in African savannas', Ecosystems 17, 808-819. https://doi.org/10.1007/s10021-014-9761-9

Jouquet, P., Traoré, S., Choosai, C., Hartmann, C. \& Bignell, D., 2011, 'Influence of termites on ecosystem functioning. Ecosystem services provided by termites', European Journal of Soil Biology 47, 215-222. https://doi.org/10.1016/j.ejsobi. 2011.05.005

Levick, S.R., Asner, G.P., Chadwick, O.A., Khomo, L.M., Rogers, K.H., Hartshorn, A.S. et al., 2010b, 'Regional insight into savanna hydrogeomorphology from termite mounds', Nature Communications 1, 1-7. https://doi.org/10.1038/ncomms1066

Levick, S.R., Asner, G.P., Kennedy-Bowdoin, T. \& Knapp, D.E., 2010a, 'The spatial extent of termite influences on herbivore browsing in an African savanna', Biological Conservation 143, 2462-2467. https://doi.org/10.1016/j.biocon.2010.06.012

Meyer, V.W., Braack, L.E.O. \& Biggs, H.C., 2000, 'Distribution and density of Cubitermes Wasmann (Isoptera: Termitidae) mounds in the northern Kruger National Park', Koedoe 43, 57-65. https://doi.org/10.4102/koedoe.v43i1.208

Meyer, V.W., Braack, L.E.O., Biggs, H.C. \& Ebersohn, C., 1999, 'Distribution and density of termite mounds in the northern Kruger National Park, with specific reference to those constructed by Macrotermes Holmgren (Isoptera: Termitidae)', African Entomology 7, 123-130.

Meyer, V.W., Crewe, R.M. \& Braack, L.E.O., 2003, 'Estimates of food consumption by the fungus-growing termite Macrotermes natalensis in a South African savannawoodland: News and views', South African Journal of Science 99, 207-208.

Meyer, V.W., Crewe, R.M., Braack, L.E.O., Groeneveld, H.T. \& Van der Linde, M.J., 2000, 'Intracolonial demography of the mound-building termite Macrotermes natalensis
(Haviland)(Isoptera, Termitidae) in the northern Kruger National Park, South (Haviland)(Isoptera, Termitidae) in the
Africa', Insectes Sociaux 47, 390-397.

Meyer, V.W., Crewe, R.M., Braack, L.E.O., Groeneveld, H.T. \& Van der Linde, M.J., 2001 , 'Biomass of Macrotermes natalensis in the northern Kruger National Park, South Africa- the effects of land characteristics', Sociobiology 38, 431-448.

Sands, W.A., 1998, The identification of worker castes of termite genera from soils of Africa and the Middle East, CAB International, Wallingford, UK.

Schuurman, G., 2005, 'Decomposition rates and termite assemblage composition in semiarid Africa', Ecology 86, 1236-1249. https://doi.org/10.1890/03-0570

Sileshi, G.W., Arshad, M.A., Konaté, S. \& Nkunika, P.O., 2010, 'Termite induced heterogeneity in African savanna vegetation: Mechanisms and patterns', Journa of Vegetation Science 21, 923-937. https://doi.org/10.1111/j.1654-1103. 2010.01197.x

Sponheimer, M., Lee-Thorp, J., De Ruiter, D., Codron, D., Codron, J., Baugh, A.T. et al., 2005, 'Hominins, sedges, and termites: New carbon isotope data from the Sterkfontein valley and Kruger National Park', Journal of Human Evolution 48 301-312. https://doi.org/10.1016/j.jhevol.2004.11.008

Uys, V.M., 2002, A guide to the termite genera of southern Africa, Plant Protection Research Institute Handbook No. 15, Agricultural Research Council, Pretoria.

Venter, F.J., Scholes, R.J. \& Eckhardt, H.C., 2003, 'The abiotic template and its associated vegetation pattern', in J.T. Du Toit, K.H. Rogers \& H.C. Biggs (eds.), The Kruger experience: Ecology and management of savanna heterogeneity, pp. 83-129, Island Press, Washington, DC.

Wanyonyi, K., Darlington, J.P.E.C. \& Bagine, R.K.N.B., 1984, 'Checklist of the species of termite (Isoptera) recorded from east Africa', Journal of the East Africa Natural History Society and National Museum 181, 1-12.

Wilson, E.O., 2017, 'Biodiversity research requires more boots on the ground', Nature Ecology \& Evolution 1, 1590. https://doi.org/10.1038/s41559-017-0360-y 